\title{
Perunan tyvimädän esiintyminen ja hallinta siemenperunan tuotannossa
}

\author{
Asko Hannukkala ${ }^{1)}$, Ari Lehtinen ${ }^{1)}$, Terhi Rantanen ${ }^{4)}$, Elina Virtanen ${ }^{2)}$ ja Anne Rahkonen ${ }^{3)}$ \\ ${ }^{1)}$ MTT, Maa- ja elintarviketalouden tutkimuskeskus, Kasvintuotannon tutkimus, 31600 Jokioinen \\ asko.hannukkala@mtt.fi, ari.lehtinen@mtt.fi \\ ${ }^{2)}$ MTT, Maa- ja elintarviketalouden tutkimuskeskus, Alueellinen tutkimus, Pohjois-Pohjanmaan \\ tutkimusasema,Tutkimusasemantie 15,92400Ruukki, elina.virtanen@mtt.fi \\ ${ }^{3)}$ Perunantutkimuslaitos, Ruosuontie15616900Lammi, anne.rahkonen@petla.fi \\ ${ }^{4)}$ Terhi Rantanen, TR Biotech Consulting, Kikerötie 6 A 10, 96440 Rovaniemi
}

\section{Johdanto}

Piilevän tyvi- ja märkämädän hallitsematon puhkeaminen näkyviksi oireiksi yksittäisissä siemenerissä on yhä siemenperunantuotannon keskeisimpiä kasvinsuojeluongelmia. Suomessa tautia aiheuttavat Erwinia carotovora-bakteerin alalajit carotovora (Ecc) ja atroseptica (Eca). Eca aiheuttaa kasvukaudella perunan tyvien mätänemisen kiiltävänmustaksi pahanhajuiseksi bakteerilimaksi. Tartunnan saaneet kasvit kellastuvat ja kuihtuvat. Molemmat alalajit voivat mädättää mukuloita pellolla ja varastossa (Pérombelon \& Kelman 1987, Helias ym. 2000).

Bakteerit kulkeutuvat oireettomina siemenmukuloissa seuraavaan kasvukauteen. Oireiden puhkeaminen riippuu täysin bakteerien määrästä ja lisääntymisnopeudesta. Kosteus-, lämpötila- ja happiolosuhteet sekä solukon rakenne säätelevät bakteerien lisääntymistä. Siksi sama siemenerä voi bakteerien lisääntymiselle otollisissa olosuhteissa tuottaa erittäin tyvimätäisen kasvuston, mutta bakteereille epäsuotuisissa olosuhteissa taudin oireita ei esiinny lainkaan kasvustossa (Vuurde \& Vries 1994, Pérombelon 2002).

Tutkimuksen tavoitteena oli kehittää PCR-tekniikoihin perustuvia E. carotovora-bakteerien osoittamismenetelmiä, selvittää niiden avulla bakteerien ilmaantumista siemenperunan tuotantoketjuun ja tutkia viljelyteknisiä taudin hallintakeinoja.

\section{Aineisto ja menetelmät}

Vuosina 2001-03 toteutetussa Maa- ja metsätalousministeriön rahoittamassa hankkeessa kehitettiin PCR-menetelmiä piilevän tyvi- ja märkämädän tartunnan sekä Eca-alalajin määrän osoittamiseksi siemenperunoissa. Samalla selvitettiin käyttökelpoisia tilastollisia otantamenetelmiä, joilla siemenperunassa sallitut alhaiset esiintymisfrekvenssit voitaisiin osoittaa riittävän luotettavasti kohtuullisilla näytemäärillä.

Kehitettyjen PCR-menetelmien avulla seurattiin miten bakteerit lisääntyvät siemenperunan tuotanto-ketjussa mikrolisäystaimista toisen vuoden avomaanlisäykseen. Tutkimusaineisto kerättiin Suomen siemenperunakeskus Oy:n tuotannosta. Alueen jokivesistä kartoitettiin, onko niissä Eca- tai Ecc-alala-jeja. Pohjois-Pohjanmaan tutkimusaseman toteuttamissa viljelmä- ja kenttäkokeissa tutkittiin viljely-teknisiä keinoja tyvi- ja märkämädän leviämisen ja ilmenemisen vähentämiseksi tuotannossa.

\section{Tulokset ja tulosten tarkastelu \\ Piilevän tyvi-ja märkämädän osoittamismenetelmien kehittäminen}

Tutkimuksessa kehitettiin useita PCR-tekniikkaan perustuvia menetelmiä piilevän tyvi- ja märkämädän osoittamiseen versoista ja mukuloista. Näistä neljä soveltuu parhaiten erilaisten tutkimushypoteesien testaamiseen. Karkeimmalla bioPCR-menetelmällä voidaan osoittaa E. carotovorabakteerien esiintyminen kasvinäytteessä. Menetelmä ei erota bakteerin alalajeja toisistaan. Ecaspesifisellä bioPCR-menetelmällä voidaan todeta tyvimätää aiheuttavan alalajin esiintyminen näytteessä. Real-time-PCR-menetelmällä voidaan osoittaa lisäksi Eca-alalajin määrä näytteessä. Lisäksi real-time-PCR-tekniikalla voidaan todeta Eca- ja Ecc-alalajien esiintyminen yhdellä PCRajolla. Menetelmiä kehitetään edelleen siemenperunan sertifiointia varten, jotta ne soveltuisivat myös suurien aineistojen tutkimiseen.

\section{Tyvimätä siemenperunan tuotantoketjussa}

Siemenperunan tuotannon mikrolisäysaineistot todettiin täysin puhtaaksi E. carotovora-bakteereista. Kasvihuoneessa ja ensimmäistä vuotta avomaalla tuotetusta sadosta ei löydetty Eca-bakteeria, mutta Ecc-alalajia esiintyi satomukuloissa. Toisen avomaalisäysvuoden aineistosta ei myöskään löydetty piilevää tyvimätää. Toisen vuoden aineistosta pelto-oloissa oli tyvimädan oireita alle 0,0001\%:ssa 
kasveista, piilotartuntoja oli keskimäärin $0,6 \%$ :ssa satomukuloista. Piilevä E. carotovora-tartunta osoitettiin 2,8\%:ssa satomukuloista. Hygienian taso tuotantoketjussa on hyvä tyvimädän hallitsemiseksi. Eca-bakteerin todellinen merkitys tuotannossa tulisi selvittää pikaisesti.

Vuonna 2002 muutamista silmävaraisesti tyvimädän vioittamiksi arvioiduista perunan versoista ei PCR-menetelmillä pystytty osoittamaan Eca-alalajia, vaan niissä oli yksinomaan Ecc-bakteeria. Myös muutamissa kasveissa, joita pidettiin selvästi perunaseitin vioittamina, PCR-analyysi paljasti Ecabakteerin. Lisäksi varsien yläosissa mädättäjänä oli Ecc-alalaji (Kuva 1).
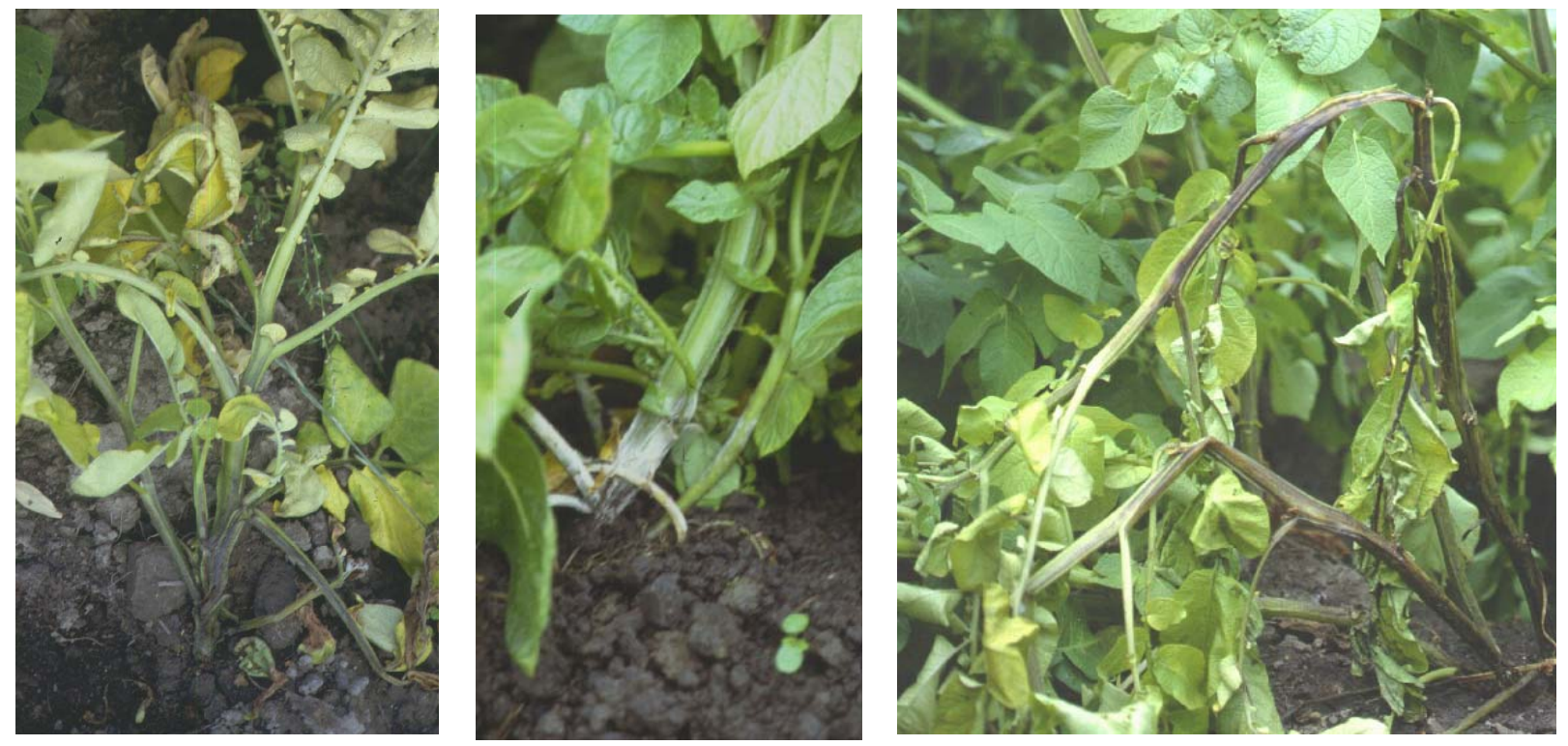

Kuva 1. Oireiden perusteella tyvimätäiseksi (vasemmalla) arvioiduista kasveista löytyi toisinaan vain Eccalalajia ja perunaseitin vioittamaksi (keskellä) arvioiduista kasveista löytyi Eca-alalajia. Kesällä 2002 Eccbakteeri vioitti joskus varsien yläosia (oikealla). Kuvat Asko Hannukkala.

\section{Viljelytekniset keinot tyvimädän hallitsemiseksi}

Viljelyteknisten tyvimädän hallintakeinojen tärkeimmät tutkimuskohteet ovat olleet Ca-lannoituksen ja varsistonhävitys- ja kastelumenetelmien vaikutus tyvimädän puhkeamiseen. Lannoituksella aikaansaatu mukuloiden Ca-pitoisuuden lisäys vähensi sadon mätänemisherkkyyttä. Varsistonhävitysmenetelmien vaikutusta tyvi- ja märkämätään ei voitu osoittaa, koska kokeissa oli liian vähän tautia hypoteesien testaamiseksi. Tutkituista vesinäytteistä ei löydetty Eca-alalajia. Vuonna 2002 Ecc-bakteeria oli suurimmassa osassa vesinäytteitä. Kuivana kesänä 2003 vain 3 näytettä oli Ecc:n saastuttamia.

\section{Johtopäätökset}

Eca- ja Ecc-bakteerien keskinäisen merkityksen tarkka selvittäminen on edellytys tehokkaiden tyvi- ja märkämädän hallintakeinojen laatimiseksi tulevaisuuden perunantuotantoon. Siemenperunan sertifioinnissa resurssit tulisi kohdentaa piilevän bakteeritartunnan selvittämiseen mukulasadosta kasvustohavaintojen sijasta. PCR-tekniikkoihin perustuvia menetelmiä tulee kehittää edelleen niin, että soveltuvat siemenperunan massatestauksiin.

\section{Kirjallisuus}

Harju, P. \& Kankila, J. 1993. Erwinia carotovora contamination of Finnish seed potatoes and the prevalence of bacterial subspecies and serogroups. Agricultural Science in Finland 2:345-352.

Helias, V., Andrivon, D., \& Jouan, B. 2000. Development of symptoms caused by Erwinia carotovora ssp. atroseptica under field conditions and their effects on the yield of individual potato plants. Plant Pathology 49:23-32.

Pérombelon, M. C. M. 2002. Potato diseases caused by soft rot erwinias: an overview of pathogenesis. Plant Pathology 51:1-12.

Pérombelon, M. C. M. \& Kelman, A. 1987. Blackleg and other potato diseases caused by soft rot Erwinias: proposal for revision of terminology. Plant Disease 71:283-285.

Vuurde, J. W. L. van \& Vries. M. De. 1994. Population dynamics of Erwinia carotovora subsp. atroseptica on the surface of intact and wounded seed potatoes during storage. Journal of Applied Bacteriology 76:568-575. 